I emphasize that the actions in these two examples are of a different character than the action taken by the General Assembly in the context of Syria, they similarly demonstrate contributions that the Assembly may make in the broader context of questions regarding peace and security.

The various ways in which the General Assembly may act--from adopting resolutions, to actions regarding credentials or the suspension of membership in subsidiary bodiesreinforce the concept that the Security Council, as confirmed by the International Court of Justice in the Certain Expenses case, is not the exclusive body with authority to act with respect to issues of peace, security, and international order. Rather, there is a wide range of actions that the principal and subsidiary organs of the United Nations may take within their authority that can play a significant role in impacting and helping to resolve conflicts across the globe.

As we meet this morning, the General Assembly has called for an end to the violence, withdrawal of Syrian troops, and a political transition to a democratic, pluralistic political system. The Security Council has echoed these sentiments. The Secretary-General has similarly called for an end to the violence, the commencement of a political dialogue, and the adoption of Kofi Annan's six-point proposal. All of these actions have been taken within the established legal framework of the United Nations. Additional steps could be taken within this framework.

It is my submission that a sustained failure on the part of the United Nations effectively to address situations like that in Syria would in time undermine the institutions of the existing international order, including the United Nations. For this reason, and for the people of Syria, it is to be fervently hoped that a solution to the situation in Syria will be found and acted upon as soon as possible.

\title{
Syria, the United Nations, and the Responsibility to Protect
}

\section{By Saira Mohamed}

The crisis in Syria has exposed both the power and the fragility of the UN system, and it has highlighted the limited power exerted by norms of intervention to sway governments to action. I focus in this brief comment on one aspect of the situation: the question of a responsibility to protect (R2P), and what we can learn about R2P from the activities of the United Nations in Syria.

R2P began as an idea put forward by the International Commission on Intervention and State Sovereignty (ICISS), an independent body established in response to the failures of the international community in Rwanda, Bosnia, and Kosovo. ${ }^{1}$ Facing questions not only about how to generate political will to intervene in humanitarian crises, but also about how to overcome the paralyzing force of the Security Council veto, the ICISS articulated as the core of R2P the notion that "sovereignty implies responsibility.", As a result of this foundational understanding, the ICISS asserted in its 2001 report that every government has a responsibility

\footnotetext{
Assistant Professor of Law, University of California at Berkeley School of Law.

'Int'l Comm'n on Intervention and State Sovereignty [ICISS], The Responsibility to Protect 1 (2001); see also Saira Mohamed, Taking Stock of the Responsibility to Protect, 48 STAN. J. INT'L L. (forthcoming 2012); Carsten Stahn, Responsibility to Protect: Political Rhetoric or Emerging Legal Norm?, 101 AJL 99 (2007).

${ }^{2}$ ICISS, supra note 1 , at $\mathrm{xi}$.
} 
to protect its own people. Moreover, if a government fails this duty, then the international community has a responsibility to step in and intervene. ${ }^{3}$

R2P encapsulates a range of actions. Beyond urging reaction to atrocities, it also consists of a responsibility to prevent and a responsibility to rebuild. ${ }^{4}$ Nonetheless, it is the responsibility to react that has earned the most attention, and it is the responsibility of the international community, rather than that of the territorial government, that has generated the most controversy. ${ }^{5}$ This controversy is at least somewhat unwarranted, as the ICISS was relatively measured in its call for a new sense of responsibility on the part of the international community. Contrary to some interpretations, it did not advocate an overthrow of Article 2(4) of the UN Charter; instead, it recommended that military intervention, when necessary, should take place through the Security Council. ${ }^{6}$ The report warned, however, that should the Security Council fail to discharge its responsibility to protect, it might suffer a crisis of legitimacy. Still, the ICISS did not go so far as to recommend that individual states should undertake military intervention without Council authorization. Instead, the report notes that states " may not rule out other means" to discharge their responsibility if the Council fails to act. ${ }^{7}$ "[M]ay" should be read as "might" —an expression of possibility, but not of permission; states might act outside of the Council, so the Council should be careful to take seriously its responsibility for international peace and security. ${ }^{8}$

The original ICISS report thus urged a responsibility on the part of the Security Council to take action in the face of massive human rights abuses. After R2P made its way through the United Nations, however, it looked quite different. The concept was taken up in debate at the 2005 World Summit, and the resulting Outcome Document included a section on R2P. This was heralded as a triumph, an "embrace" of R2P. ${ }^{9}$ A closer look at what was adopted in the Outcome Document, however, makes clear that this was a drastically stripped-down version of the concept. The Outcome Document expressed support for the notion that a government has a responsibility toward its own people, ${ }^{10}$ and it recognized the international community's responsibility "to use appropriate diplomatic, humanitarian and other peaceful means ... to help protect populations from genocide, war crimes, ethnic cleansing, and crimes against humanity." 11 With respect to coercive measures, however, the Outcome Document diverged sharply from the ICISS's original proposal. Instead of articulating any responsibility, the Outcome Document stated only that governments were "prepared" to use coercive measures "on a case-by-case basis." 12 By the time the concept emerged from the United Nations, there was little responsibility left in the responsibility to protect.

Having considered what R2P is and what it is not, I will turn to the question of what we can learn about the concept from recent events in Syria. To answer this question, we should look beyond Syria, and also consider Libya. Just over a year ago, the Security Council

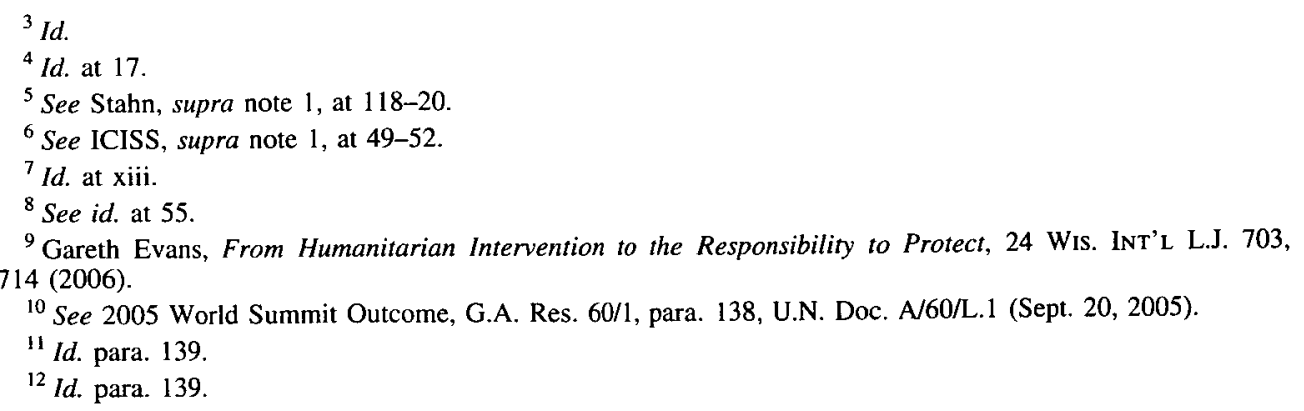


decision to authorize the use of force in Libya inspired excited cries that R2P had triumphed. ${ }^{13}$ It was said that we had a "new politics of protection" in the UN Security Council. ${ }^{14}$ In his opening address to the General Assembly in the fall of 2011, Secretary-General Ban Kimoon announced, "It should be clear to all that [R2P] has arrived.",15

When we fast-forward only few months, and shift our gaze away from Libya, we hear equally heated cries that Syria spells the end of R2P. ${ }^{16}$ The Security Council's inability to adopt a resolution; ${ }^{17}$ the fact that military force appears off the table even for states that do support some kind of intervention; ${ }^{18}$ the omission of any reference to R2P in the Council's statements even with regard to Syria's responsibility to its own people_-all of these failures seem to sound the death knell for the principle. I would caution, however, that before we deem this the end of R2P, we should consider that there is more to the concept than military intervention. Indeed, the ICISS asserted that military intervention should be undertaken only in "extreme cases," 19 and that R2P should include diplomatic measures, economic sanctions, and informal tools of pressure and criticism. ${ }^{20}$

Moreover, there is more to R2P than the Security Council. The Arab League suspended Syria from membership; prohibited travel by Syrian officials; froze Syria's assets; and sent an observer mission to Syria to monitor protection of civilians. ${ }^{21}$ The United States, European Union, and others have imposed diplomatic and economic sanctions against President Bashar al-Assad and the ruling regime. ${ }^{22}$ The UN General Assembly demanded that the Syrian government cease violence against civilians and commit to a political process. ${ }^{23}$ These are all manifestations of R2P. Recognizing them as such may help broaden commentators' narrow focus on military intervention. Moreover, identifying these efforts as ways to fulfill the responsibility of the international community may reassure states that fear that the concept is mere pretext for military adventurism by imperialist states. ${ }^{24}$ The Libyan intervention already has given R2P a "bad name," said Indian UN representative Hardeep Singh Puri, so perhaps we can see in these varied efforts some cause for relief. ${ }^{25}$

Still, ultimately R2P centers on avoiding the inconsistency of the $1990 \mathrm{~s}$, when some crises were worthy of intervention and others were not; and what we see on the part of the Security Council right now appears to be inconsistency. ${ }^{26}$ Moreover, even beyond the failure of the

\footnotetext{
${ }^{13}$ See S.C. Res. 1973, U.N. Doc. S/RES/1973 (Mar. 17, 2011).

${ }^{14}$ Alex J. Bellamy \& Paul D. Williams, The New Politics of Protection? Côte d'Ivoire, Libya and the Responsibility to Protect, 87 INT'L AFF. 825, 847 (2011).

${ }^{15}$ U.N. Secretary-General Ban Ki-moon, Remarks at Breakfast Roundtable with Foreign Ministers, Sept. 23, 2011, http://www.un.org/apps/news/infocus/sgspeeches/search_full.asp?statID=1325.

${ }^{16}$ See, e.g., David Rieff, R2P, R.I.P, INT' L Her. Trib., Nov. 8, 2011, at 6; Elliott Abrams, R2P, R.I.P, Pressure PoINTs (Mar. 8, 2012), http://blogs.cfr.org/abrams/2012/03/08/r2p-r-i-p/.

${ }^{17}$ See Saira Mohamed, The U.N. Security Council and the Crisis in Libya, ASIL Insights (Mar. 26, 2012), http://www.asil.org/insights 120326.cfm.

${ }^{18}$ See, e.g., Neil MacFarquhar, Syrian Clashes Continue as Forces Scramble to Scrub Signs of Homs Assault, N.Y. TImes, Mar. 7, 2012, at A6 (quoting statement by President Barack Obama that "[f]or us to take military action ... is a mistake'').

${ }^{19}$ ICISS, supra note 1, at 16; see also id. at 32 (describing criteria for intervention).

${ }^{20}$ See id. at 8 (describing the scope of the concept).

${ }^{21}$ See Neil MacFarquhar \& Nada Bakri, Isolating Syria, Arab Group Sets Broad Sanctions, N.Y. TIMEs, Nov. 28, 2011, at A1.

${ }^{22}$ See Q\&A: Syria Sanctions, BBC NEws (Mar. 23, 2012), http:/www.bbc.co.uk/news/world-middle-east15753975

${ }^{23}$ Rick Gladstone, General Assembly Votes to Condemn Syrian Leader, N.Y. Times, Feb. 17, 2012, at A12.

${ }^{24}$ See generally Ryan Goodman, Humanitarian Intervention and Pretexts for War, 100 AJIL 107 (2006).

${ }^{25}$ See Charles Homans, Just What Is a Just War?, Foreign POL'Y, Nov. 2011, at 34, 35.

${ }^{26}$ See ICISS, supra note 1, at 5-6; Mohamed, supra note 1 (manuscript at 17-18) (on file with author).
} 
Council in Syria, I would posit that we cannot confidently say that Libya was a triumph of R2P. Libya did not necessarily signal a new politics of protection, as much as it marked a coincidence of national interests and protection interests. ${ }^{27}$ To admit this is not to attack the idea of R2P; even the ICISS admitted that "unless . . political will can be mustered ... when action is called for, the debate about human protection purposes will largely be academic. " ${ }^{28}$ R2P seeks to motivate states to intervene even when they do not have particular national interests driving them to do so-or even better, to convince states that it is within their particular national interests to support intervention. That is the real challenge of R2P. And both Libya and Syria show us that we are not there yet.

$\mathrm{R} 2 \mathrm{P}$ is a principle that has no direct means of enforcement. It relies on shame, on criticism, on pressure. But as we have seen, states are willing to withstand shaming efforts when it comes to the question of intervention to protect human rights, military or otherwise. And beyond that, shame has little impact when there is no agreement on the appropriate course of action. ${ }^{29}$ R2P might place some pressure on states at the margins, but it seems that its force is not so strong as to motivate a state to act in contravention of other interests. The longer we assume that shame is sufficient to motivate otherwise unwilling states to support coercive intervention to protect human rights, the longer we will be expressing disappointment in the international community.

\section{Shift in Dynamics of Chapter VII Function of The Security Council}

\section{By Mahnoush H. Arsanjani*}

The Syrian problem is only the latest in a series of conflicts-over the last two decadeswhich have exposed the shifting dynamics of the Security Council's Chapter VII functions.

The burst of optimism after the Cold War as to an effective role for the Security Council in dealing with international conflicts involving high levels of violence soon dissipated. The cooperative posture of a diminished Russia was succeeded by a reassertion of the new Russia of its status as a global power. At the same time, an increasingly reassured and economically powerful China became a more important actor on the international scene with its own aspirations. If this sounds like the reemergence of a dynamic not too far from the Cold War, why should it not have a paralyzing effect on the Security Council's ability to deal with conflicts similar to the one we saw during the Cold War?

But there is more. At least five other factors have affected the Chapter VII dynamics of the Security Council. First, the increasing demand of regional organizations to play a key role, at least at the policy level, about how to address serious disturbances in or caused by a regional delinquent state. Second, the increasing need for robust military force and firepower in enforcement actions by the Security Council. Third, the inability of the organization to muster such a force from the contributions of a large number of states willing and able to contribute to and to operate under UN command and control. Fourth, the unavailability of a sufficient number of highly trained military personnel and military material in many states due to their shrinking military budgets. And fifth, beyond the traditional peacekeeping

${ }^{27}$ See Mohamed, supra note 1 (manuscript at 15-16).

${ }^{28}$ ICISS, supra note 1 , at 70.

${ }^{29}$ See Anne Orford, International Authority and the Responsibility to Protect 22 (2011); Alex J. Bellamy, Whither the Responsibility to Protect: Humanitarian Intervention and the 2005 World Summit, 20 ETHICS \& INT'L AFFs. 143, 148-49 (2006).

* Of International Law Associates. 